\title{
THE CORRELATIVE ANALYSIS OF AMPLITUDE-TEMPORAL CHARACTERISTICS OF EVOKED POTENTIALS OF BRAIN CORTEX IN SPORTSMEN
}

\author{
Alona Romaniuk \\ Department of Human and Animal Physiology \\ Lesya Ukrainka Eastern European National University \\ 13 Voli ave., Lutsk, Ukraine, 43025 \\ romaniuk.alona@mail.ru \\ Tetiana Shevchuk \\ Department of Human and Animal Physiology \\ Lesya Ukrainka Eastern European National University \\ 9 Potapova str., Lutsk, Ukraine, 43025 \\ tetyana_shevchuk_2013@ukr.net \\ Tetiana Poruchynska \\ Department of Human and Animal Physiology \\ Lesya Ukrainka Eastern European National University \\ 9 Potapova str., Lutsk, Ukraine, 43025 \\ tanya.poruch@gmail.com \\ Oleksandr Zhuravlov \\ Department of Human and Animal Physiology \\ Lesya Ukrainka Eastern European National University \\ 9 Potapova str., Lutsk, Ukraine, 43025 \\ qwota@ukr.net \\ Oksana Usova \\ Department of health and physical rehabilitation \\ Lesya Ukrainka Eastern European National University \\ $2 b$ Hrushevskoho str., Lutsk, Ukraine, 43000 \\ alex_uas@ukr.net
}

\begin{abstract}
The article considers the correlative analysis of amplitude-temporal characteristics of evoked potentials of brain cortex in sportsmen of playing kinds of sport and athletes at perception and processing of significant information "What" and "Where" in the brain cortex. The method of electroencephalography (P300 methodology) was used to study the evoked potentials of the brain cortex. The statistical processing of data was realized using the statistical package MedStat. Kendall coefficient of correlation was used depending on data distribution, different from the normal values distribution. In the result of research there were revealed the high interconnections of latency of later components in sportsmen of both groups of examined persons at observation of significant stimuli "What" and "Where". There was revealed the intensification of correlations of latency in frontal, central and temporal parts of the brain cortex. The correlations of amplitude of late components of biopotentials of the brain cortex were characterized with mean coefficients of interconnection mainly in sagittal central frontal and also parietal parts of cortex.
\end{abstract}

Keywords: evoked potentials, amplitude-temporal characteristics, sportsmen of playing kinds of sport, athletes.

DOI: 10.21303/2504-5695.2017.00309

(C) Alona Romaniuk, Tetiana Shevchuk,

Tetiana Poruchynska, Oleksandr Zhuravlov, Oksana Usova

\section{Introduction}

The scientists made a great contribution in the solution of problem of bioelectric activity of the brain cortex in sportsmen. Especially, it is a study of the features of cortex electric activity 
at cognitive activity of sportsmen [1], somatosensory evoked potentials of cortex in professional athletes [2], specific changes of somatosensory evoked potentials and time of basketball players' reaction [3]. The extremely slow electric activity of brain at short-term hypoxic stress in sportsmen is also studied for today [4], the features of visual, auditory and cognitive evoked potentials of brain in sportsmen are revealed [5], and the evoked potentials of brain in sportsmen of single combats are also characterized [6], the correlations between the evoked potentials of brain and the level of special physical readiness of footballers are established [7].

The series of scientists in their works accent the fact that the success of sportsman depends not only on his physical qualities but also on cognitive abilities [7,8]. At the same time the result of complex study of the features of cognitive functions and correlative analysis of amplitude-temporal characteristics of evoked potentials of the brain cortex in sportsmen of playing kinds of sport and athletics that are very important for attaining the high professional results are practically absent.

\section{Aim of research}

To establish the characteristics of correlations of amplitude-temporal characteristics of evoked potentials of the brain cortex in sportsmen of playing kinds of sport and athletes at perception and processing of visual information in the brain cortex.

\section{Methods of research}

The examination was carried out in laboratory of Age neurophysiology of Ecologic physiology of the department of human and animal physiology of biological faculty of Eastern European University, named after Lesya Ukrainka. It was carried out using the program complex "Neurocom" by the method of electroencephalography (method of evoked potentials). The amplitude and latency of evoked potentials of the brain cortex in sportsmen were analyzed. The stimuli material of examined person was elaborated as two series. The examined contingent received two series of stimuli on the screen - significant and insignificant ones. The first series "What" consisted of 100 stimuli, the examined persons had to react to the appearance of green ball. The other series "Where" is 100 stimuli, the examined persons had to react to the green ball only if it is in the left upper corner of the screen.

The examination included 140 male persons. The number of examined persons was 70 persons in each group. The calculation of the sample volume was realized using the module Experiment planning in statistic package MedStat [8]. At calculation of the sample volume the significance level was equal to $5 \%$, and the force $-80 \%$. The standard deviation is 3,9 conventional units for amplitude characteristics and 88 for latency, and also biologically significant effect is 2 for amplitude and 40 for latency. All they were the sportsmen of different specialization and qualification, 7-25 years old. The sportsmen were healthy, according to the data of somatic and psychoneurological examination. All examined persons were right-handed by the type of manual asymmetry. The right-handedness was determined by the leading hand at writing.

According to the sport specialization, they were divided in two groups: I group - the sportsmen of playing kinds of sport (basketball, volleyball, football) II group - the sportsmen-athletes (sprinter, stayer, sport walking). The sportsmen had the sport rank of sport master of international class (SMic), sport master (MC) and also the sport categories from III to candidate for sport master (CSM).

The correlative analysis of amplitude and latency of evoked potentials of the brain cortex was realized using non-parametric method of Kendall pair correlation in statistical package MedStat. The correlation coefficient $r$ may have the values from -1 to +1 . The stronger the correlation is, the more $r$ value.

\section{Results of research}

At the research there were examined the correlation between amplitude and latency of late components of evoked potentials of the brain cortex in sportsmen of playing kinds of sport and athletes at perception and processing of information.

The analysis of latency P3 demonstrated the strong inter-hemisphere and intra-hemisphere connections in the brain cortex. The strong inter-hemisphere connections were observed in frontal, 
parietal and temporal parts of the brain cortex. The intra-hemisphere connections were detected between occipital and temporal parts in the left hemisphere of the brain cortex at observation of the series of stimuli "What" in sportsmen-athletes (Fig. 1, a).

In sportsmen of playing kinds of sport were also observed the strong positive inter-hemisphere and intra-hemisphere connections in front and back associative parts of the brain cortex (Fig. 1, b).

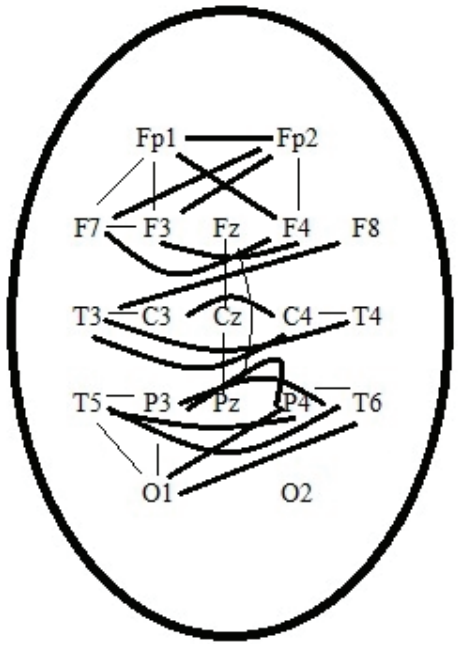

$a$

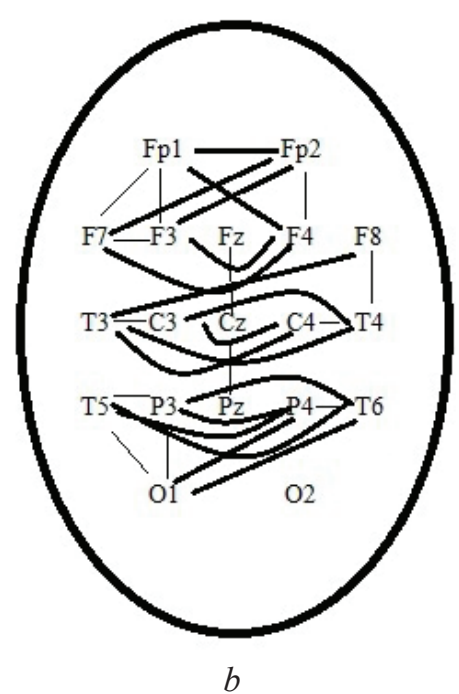

Fig. 1. The features of correlations of $\mathrm{P} 3$ component latency at the series of stimuli "What":

$a$ - in sportsmen-athletes; $b$ - in sportsmen of playing kinds of sport;

- - intra-hemisphere connections; $\_$- inter-hemisphere connections)

At the analysis of closeness of latency connection the inter-hemisphere connections of parietal parts of cortex and occipital parts with parietal ones of the brain cortex must be noted. As far as the late components are responsible for making decisions at realization of set task, the specificity of connections in two groups of sportsmen must be noted. In playing kinds of sport are observed the connections in parietal and central parts, responsible for perception and processing of object placing and in athletes the temporal parts, responsible for object recognition.

Analyzing P3 latency at observation of significant stimuli "What" the close positive interhemisphere and inter-hemisphere correlations were established in occipital-temporal direction and front associative parts of the brain cortex in sportsmen-athletes (Fig. 2, a). At the same experimental situation in sportsmen of playing kinds of sport were fixed the correlations in occipital-central direction and also the inter-hemisphere connections between temporal and frontal parts (Fig. 2, b).

At analysis of P2-N2 amplitude in sportsmen as a result of perception and processing of information as an object the high and very high forces of connection were not revealed. It can be only noted the mean inter-hemisphere connections in frontal and temporal parts of athletes. In sportsmen of playing kinds the inter-hemisphere mean connections between frontal and central parts of the brain cortex were revealed.

The amplitude of late evoked potentials was characterized with close inter-hemisphere positive correlative connections in frontal, parietal and central parts and also with sagittal frontal and sagittal central ones in sportsmen-athletes at perception and processing of object localization (Fig. 3, a). The close inter-hemisphere connections in frontal parts and in direction from sagittal frontal to sagittal parietal parts of the brain cortex were established in players (Fig. 3, b).

At the study of correlations of N3 latency were established the inter-hemisphere mutual connections between the frontal and temporal parts and between occipital and temporal parts in sportsmen-athletes at perception and processing of information as an object (Fig. 4, a). In sportsmen of playing kinds of sport were established the high inter-hemisphere connections in front as- 
sociative the brain cortex and between occipital and parietal and also occipital and temporal parts of the brain cortex (Fig. $4, b$ ).

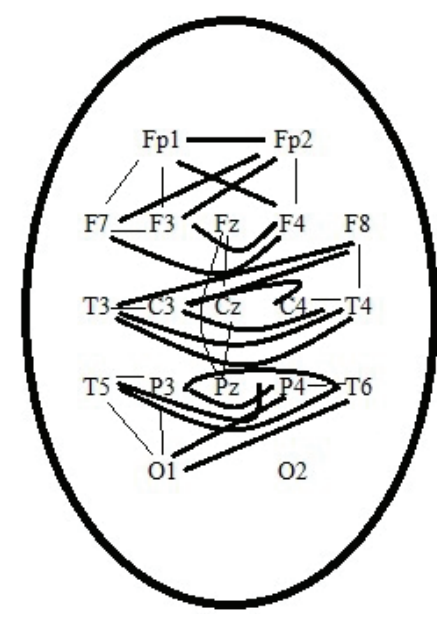

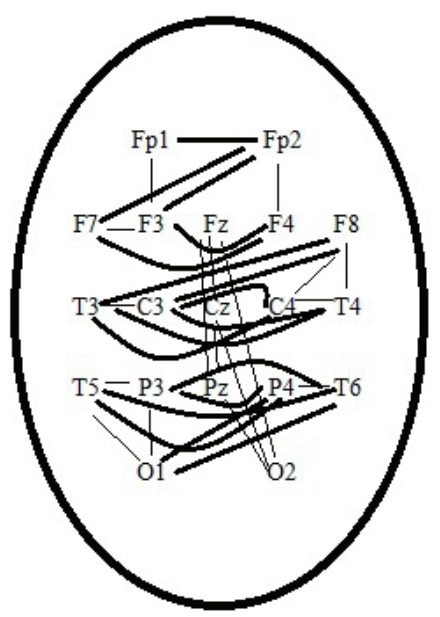

$b$

Fig. 2. The features of correlations of $P 3$ component latency at stimuli series "Where": $a$ - in sportsmen-athletes; $b$ - in sportsmen of playing kinds of sport; - - intra-hemisphere connections; — - inter-hemisphere connections

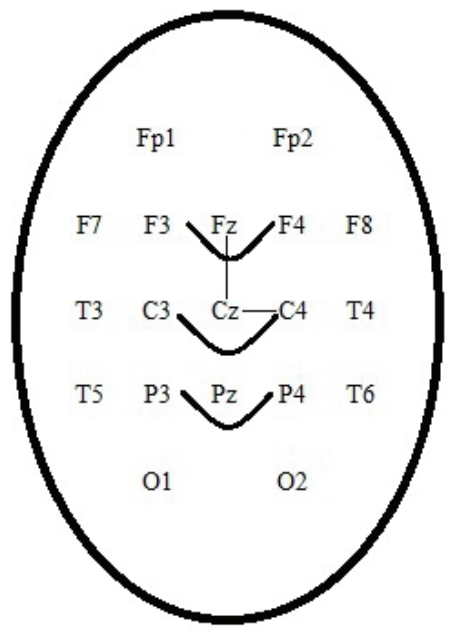

$a$

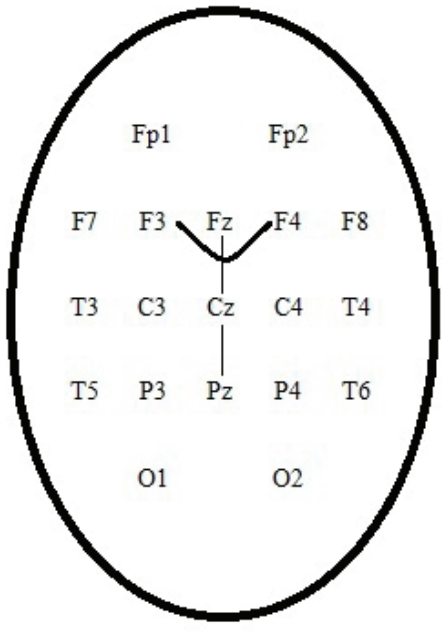

$b$

Fig. 3. The features of correlations of $\mathrm{P} 2-\mathrm{N} 2$ component amplitude at the series of stimuli "Where": $a$ - in sportsmen-athletes; $b$ - in sportsmen of playing kinds of sport;

- intra-hemisphere connections; —— - inter- hemisphere connections

At perception and processing of information as an object localization in space were revealed the high inter-hemisphere connections in front associative parts of the brain cortex and also between temporal and frontal sections, both inter-hemisphere and intra-hemisphere ones in sportsmen-athletes (Fig. 5, a). In sportsmen of playing kinds of sport at experimental situation "Where" were revealed the high correlations between occipital and sagittal frontal, central, parietal parts of cortex and also between inter-hemisphere parietal and temporal and parietal parts of the brain cortex (Fig. 5, b).

As to P3-N3 amplitude it must be noted that at two experimental situations the high correlations were not revealed in sportsmen. There were revealed the inter-hemisphere mean correlations of P3-N3 amplitude between frontal, parietal parts of brain and intra-hemisphere connections between temporal and frontal parts of the brain cortex in sportsmen of playing kinds of sport at the 
series "What". In sportsmen-athletes at this series of stimuli were established the inter-hemisphere mean connections between frontal parts and intra-hemisphere connections between occipital and parietal, sagittal frontal and sagittal central ones.

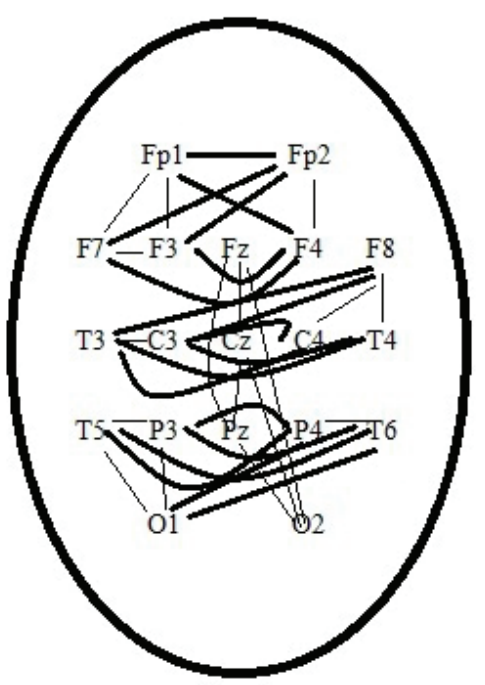

$a$

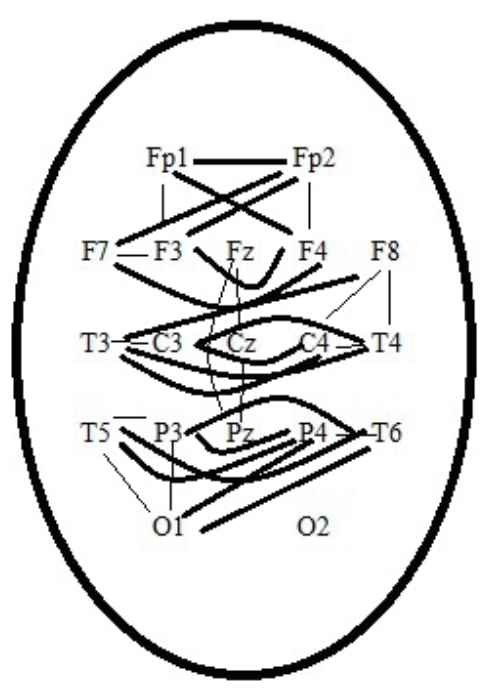

$b$

Fig. 4. The features of correlations of P2-N2 component amplitude at the series of stimuli "What": $a$ - in sportsmen-athletes; $b$ - in sportsmen of playing kinds of sport;

- intra-hemisphere connections; —— - inter- hemisphere connections

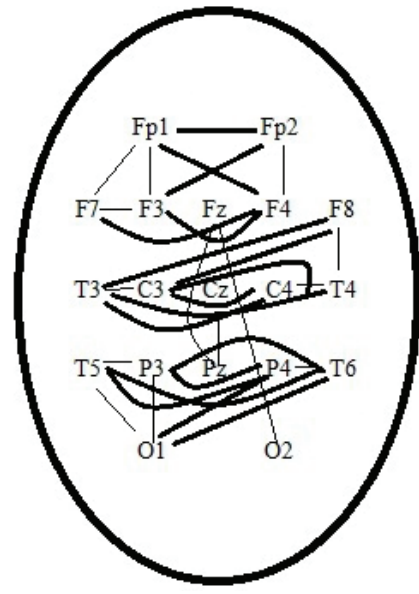

$a$

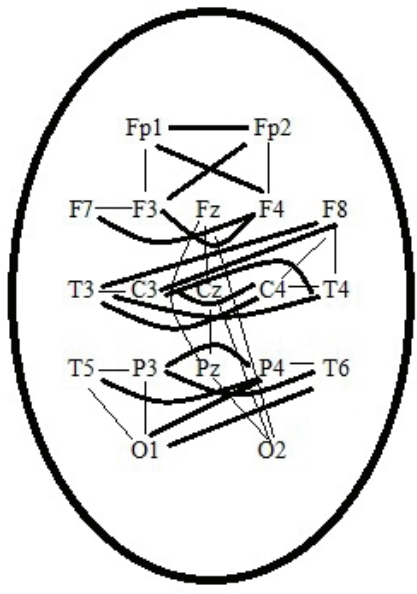

$b$

Fig. 5. The features of correlations of N3 component latency at the series of stimuli "Where": $a$ - in sportsmen-athletes; $b$ - in sportsmen of playing kinds of sport; - intra-hemisphere connections; - - inter- hemisphere connections

At the series of stimuli "Where" in sportsmen-athletes were established the mean correlative inter-hemisphere connections between frontal, central, parietal parts of cortex and intra-hemisphere ones between central and temporal, temporal and parietal, occipital and parietal parts of the brain cortex. At reacting to the significant stimulus as an object placing, in sportsmen of playing kinds of sport were established the mean inter-hemisphere correlations between frontal, parietal, occipital parts of the brain cortex and intra-hemisphere connections between frontal and central, temporal and central, parietal and central, occipital and central parts of the brain cortex.

Thus, having analyzed the specificity of correlations, the high forces of latency connection of late components were established in sportsmen of both groups of examined persons at observa- 
tion of significant stimuli "What" and "Where". There were revealed the intensification of latency correlations in frontal, central and temporal parts of the brain cortex. The correlations of amplitude of the late components of the brain cortex biopotentials were characterized with mean correlation forces mainly in sagittal central frontal and also parietal parts of cortex.

\section{Discussion of the results of research}

The analysis of latency and amplitude correlations of EP late components demonstrated that the sportsmen-athletes were characterized with more dense inter-hemisphere correlations in front associative parts of the brain cortex and intra-hemisphere in occipital-parietal direction of the left hemisphere of the brain cortex. In players was observed the more dense correlations that included both front and back associative parts of the brain cortex.

The less density of correlation was observed in rates of EP late components, they were mainly characterized with mean interconnections of inter-hemisphere interactions in central parts of the brain cortex and between parietal parts in sportsmen of playing parts of sport at significant stimuli as object localization in space.

The authors $[10,11]$ indicate that the functional organization of hemispheres of the brain cortex is important, because the human nervous system is built in such a way that each hemisphere of brain receives information mainly from the opposite side of the body. This principle of contralateral projection is related to both general corporal, tactile sensitivity and to the sight and hearing, although the picture is not unambiguous as to the last ones. But the use of correspondent methods allows give information selectively in one hemisphere only and in such a way to reveal the significant divergences in functional abilities of two hemispheres. As a result of analysis of correlations of amplitude and latency of the brain cortex evoked potentials, our data are agreed with the conclusion of these scientists [10-12], that is manifested in high intra-hemisphere and inter-hemisphere interconnections.

The most studied inter-hemisphere interconnections are the ones at visual and auditory perception. As it is shown by the clinical studies, the destruction of central visual zones in one hemisphere results in loss of the opposite half of vision field (the right one at left-side lesion and the left one - at right-side one). Knowing the place of visual cortex lesion, the sight loss can be prognosticated. But it is difficult to foresee the human reaction to such lesion, because human nervous system has compensatory possibilities [13].

Among hypotheses as to the nature of inter-hemisphere divergences at visual perception there are two widespread ones: one of them connects these divergences with verbalization of perceived stimuli; according the other one, the divergences are generated by the features of work style of each hemisphere - analytic for the left and integral global for the right one. In general there is a dominating point of view that the advantage of one or another hemisphere at perception of visual stimuli is determined by the ratio of two stages of procession: optic-space one that the right hemisphere prevails in and verbalization processes, realized by the left one $[11,14,15]$. The study of interconnections of amplitude-temporal characteristics of the brain cortex evoked potentials in sportsmen at perception and processing of significant information "What" and "Where" demonstrated these correlations, manifested in the density of connections in temporal parts at perception and processing of information "What" and in parietal ones - at information "Where".

The attempts to explain the inter-hemisphere divergences on the base of neurons specialization in perceptive process are realized. The well-known model in this aspect is the one that ascribes certain specialization to the brain hemispheres as to the processing of different space frequencies. According to these suggestions, the frequency filtration is realized differently in visual centers of one or another hemisphere. The right hemisphere is mainly connected with perception of objects outlines and their big details. The left one, on the contrary, is responsible for perception of little details of the picture [16-18]. The data are agreed with complementary principle, when the left hemisphere outgoes the right one in perception of information, and the right one, getting information independently and through the left one, is a leading one as to the stimuli processing [19].

In general it must be noted, that the right "spatial" and left "temporary" hemispheres have their specific abilities that allows them to make a great contribution in most types of cognitive 
activity. It is obvious that the left one has more possibilities in temporal and auditory sphere and the right one - in spatial and visual ones. These features probably help the left hemisphere to find and to separate better the details that must be distinctly characterized and placed in temporal succession [20]. In its turn the one-time perception of space forms and signs by the right hemisphere probably favors the search for integrative connections and comprehension of general configurations. If such interpretation is correct, it is obvious that each hemisphere processes the same signals in its own way and transforms the sensor stimuli corresponding to the own specific strategy of their presentation $[11,21,22]$.

As to the question of functional organization of the brain cortex hemispheres in examined sportsmen, it can be said, that statistically significant difference was observed in amplitude-temporal characteristics in both right and left hemispheres of the brain cortex.

Taking into account these facts, the conclusion can be made that not only the long energetic provision of mobile activity but also the ability to fast perception and processing of information is important for attaining the high sport results. That is why the more density of correlations in left hemisphere can be explained by the processes of verbalization in athletes and in right one by the spatial characteristics, more fixed in sportsmen-players.

Obviously, it can be connected with the fact that in sport games take place the permanent situations, when it is necessary to change the moving direction, the succession of inclusion of technical elements abruptly to resist the adversary and foresee his further actions, so these sportsmen must fast react to the existent situation, to orient on the place of competitions, to concentrate on the set task. And in athletes the most significant moment in perception and processing of information is a reaction to initial irritant.

\section{Conclusions}

1. The correlative analysis of amplitude-temporal characteristics of the brain cortex evoked potentials in sportsmen of playing kinds of sport and athletes demonstrated the mean and high correlations in front and back associative parts of the brain cortex.

2. The spatial synchronization of the brain cortex biopotentials in sportsmen of playing kinds of sport was manifested in increase of the number of correlations between frontal, central and parietal parts of the right hemisphere at perception and processing of significant information "Where".

3. In athletes was revealed the intensification of correlations between frontal, occipital and temporal parts of brain cortex of the left hemisphere at perception and processing of significant information "What".

\section{References}

[1] Koryukalov, Yu. I., Maroko, D. A. (2006). Osobennosti bioelektricheskoy aktivnosti mozga pri kognitivnoy deyatelnosti u sportsmenov. Vestnik Yuzhno-Uralskogo gosudarstvennogo universiteta. Seriya: Obrazovanie, zdravoohraneniya, fizicheskaya kultura, 1 (7 (3-1)), 80-83.

[2] Enescu-Bieru, D., Calina, M. L., Avramescu, E. T., Dragomir, M. (2010). Study of somatosensory evoked potential parameters in professional athletes. Advances in biomedical research, 243-249.

[3] Yamashiro, K., Sato, D., Onishi, H., Yoshida, T., Horiuchi, Y., Nakazawa, S., Maruyama, A. (2012). Skill-specific changes in somatosensory-evoked potentials and reaction times in baseball players. Experimental Brain Research, 225 (2), 197-203. doi: 10.1007/s00221-012-3361-8

[4] Ahmadeev, R. R., Bazhin, A. V., Kalmetev, A. H. (2006). Sverhmedlennaya elektricheskaya aktivnost golovnogo mozga pri kratkosrochnom gipoksicheskom stresse u sportsmenov. Vestnik Yuzhno-Uralskogo gosudarstvennogo universiteta. Seriya: Obrazovanie, zdravoohraneniya, fizicheskaya kultura, 1 (7 (3-1)), 94-96.

[5] Zamulina, E. V. (2008). Osobennosti zritelnyih, sluhovyih ta kognitivnyih vyizvannyih potentsialov golovnogo mozga u sportsmenov. Tomsk, 78.

[6] Guzhov, F. A., Lozhkina, M. B., Kapilevich, L. V. (2013). Harakteristika vyizvannyih potentsialov golovnogo mozga u sportsmenov-edinobortsev (na primere sportivnogo karate). Vestnik Tomskogo gosudarstvennogo universiteta, 372, 148-151.

[7] Kapilevich, L. V., Zamulina, E. V. (2008). Vzaimosvyaz vyizvannyih potentsialov golovnogo mozga s urovnem spetsialnoy fizicheskoy podgotovlennosti futbolistov. Byulleten sibirskoy meditsinyi, 7 (2), 112-114. 
[8] Gurova, M. B., Kapilevich, L. V. (2013). Osobennosti vospriyatiya dvizheniy u sportsmenov v zavisimosti ot napravlennosti trenirovochnogo protsessa. Byulleten sibirskoy meditsinyi, 12 (2), 195-199.

[9] Lyah, Yu. E., Guryanov, V. G., Homenko, V. E., Panchenko, O. A. (2006). Osnovyi kompyuternoy biostatistiki: analiz informatsii v biologii, meditsinyi i farmatsii statisticheskim paketom MedStat. Donetsk, 211.

[10] Fomina, E. V. (2006). Funktsionalnaya asimmetriya mozga i adaptatsiya cheloveka k ekstremalnyim sportivnyim zagruzkam. Tyumen, 40.

[11] Rauschecker, J. P., Tian, B. (2000). Mechanisms and streams for processing of "what" and "where" in auditory cortex. Proceedings of the National Academy of Sciences, 97 (22), 11800-11806. doi: 10.1073/pnas.97.22.11800

[12] Loic, P., Milhau, A., Chesnoy-Servanin, G., Ferrier, L. P., Brouillet, T., Heurley, D. B. (2012). Influence of Language on Colour Perception: A Simulationist Explanation. Biolinguistics, 354-382.

[13] Yamashiro, K., Sato, D., Onishi, H., Yoshida, T., Horiuchi, Y., Nakazawa, S., Maruyama, A. (2012). Skill-specific changes in somatosensory-evoked potentials and reaction times in baseball players. Experimental Brain Research, 225 (2), 197-203. doi: 10.1007/s00221-012-3361-8

[14] Bedanokova, L. Sh. (2012). Vliyanie sportivnyih nagruzok razlichnoy trenirovochnoy napravlennosti na kognitivnyie funktsii studentov. Vestnik Adyigeyskogo gosudarstvennogo universiteta. Seriya 4: Estestvenno-matematicheskie i tehnicheskie nauki, 4 (110), 52-55.

[15] Lee, A. K. C., Larson, E., Maddox, R. K., Shinn-Cunningham, B. G. (2014). Using neuroimaging to understand the cortical mechanisms of auditory selective attention. Hearing Research, 307, 111-120. doi: 10.1016/j.heares.2013.06.010

[16] Zhavoronkova, L. A., Belostotskiy, A. P., Holodova, N. B., Kulikov, M. A., Kuptsova, S. V., Oknina, L. B. (2010). EEG i VP-markeryi narusheniya asimmetrii mozga posle vozdeystviya radiatsii (posledstviya Chernobyilskoy avarii). Sovremennyie napravleniya $v$ issledovanii funktsionalnoy mezhpolusharnoy asimmetrii i plastichnosti mozga. Moscow, 26.

[17] Nakata, H., Yoshie, M., Miura, A., Kudo, K. (2010). Characteristics of the athletes' brain: evidence from neurophysiology and neuroimaging. Brain Research Reviews, 62 (2), 197-211. doi: 10.1016/ j.brainresrev.2009.11.006

[18] Bokura, H., Yamaguchi, S., Kobayashi, S. (2001). Electrophysiological correlates for response inhibition in a Go/NoGo task. Clinical Neurophysiology, 112 (12), 2224-2232. doi: 10.1016/s13882457(01)00691-5

[19] Murakami, T., Sakuma, K., Nakashima, K. (2008). Somatosensory evoked potentials and high-frequency oscillations in athletes. Clinical Neurophysiology, 119 (12), 2862-2869. doi: 10.1016/j.clinph.2008.09.002

[20] Banerjee, A., Pillai, A. S., Horwitz, B. (2012). Using large-scale neural models to interpret connectivity measures of cortico-cortical dynamics at millisecond temporal resolution. Frontiers in Systems Neuroscience, 5. doi: 10.3389/fnsys.2011.00102

[21] Abrams, D. A., Nicol, T., Zecker, S., Kraus, N. (2008). Right-Hemisphere Auditory Cortex Is Dominant for Coding Syllable Patterns in Speech. Journal of Neuroscience, 28 (15), 3958-3965. doi: 10.1523/ jneurosci.0187-08.2008

[22] Sokhadze, E. M., Baruth, J. M., Sears, L., Sokhadze, G. E., El-Baz, A. S., Williams, E. L. et. al. (2012). Event-Related Potential Study of Attention Regulation During Illusory Figure Categorization Task in ADHD, Autism Spectrum Disorder, and Typical Children. Journal of Neurotherapy, 16 (1), 12-31. doi: 10.1080/10874208.2012.650119 